\title{
Monitoring the Error Rate of Modern Methods of Construction Based on Wood
}

\author{
Jozef Švajlenka, Mária Kozlovská \\ Technical University of Košice, Slovakia \\ Civil Engineering Faculty, Institute of Construction Technology and Management \\ e-mail: jozef.svajlenka@tuke.sk, maria.kozlovska@tuke.sk
}

\begin{abstract}
A range of new and innovative construction systems, currently developed, represent modern methods of construction (MMC), which has the ambition to improve the performance parameters of buildings throughout their life cycle. Regarding the implementation modern methods of construction in Slovakia, assembled buildings based on wood seem to be the most preferred construction system. In the study, presented in the paper, were searched already built and lived-in wood based family houses. The residents' attitudes to such type of buildings in the context with declared designing and qualitative parameters of efficiency and sustainability are overlooked. The methodology of the research study is based on the socio-economic survey carried out during the years 2015 - 2017 within the Slovak Republic. Due to the large extent of data collected through questionnaire, only selected parts of the survey results are evaluated and discussed in the paper. This paper is aimed at evaluating the quality of buildings expressed in a view of users of existing wooden buildings. Research indicates some defects, which can be eliminated in the next production process. Research indicates, that some defects occur, so the production process quality should be improved in the future development.
\end{abstract}

Key words: modern methods of construction, wood construction, error

\section{Introduction}

Modern Methods of Construction (MMC) are certainly a response to the sustainability trend. Definitions of MMC in the world are different. Asia prefers the term prefabrication or industrialized building systems, UK prefer the term MMC, USA and Australia prefer the term off-site construction methods. MMC are divided into two groups the first group is off-site MMC and the second is on-site MMC. Off-site MMC comprise prefab panels or prefab modules structures. Elements of prefab construction are produced in factory and finished elements are transported to site and assembled there [1]. Generally, modern methods of construction are technologies usually which make use of structures or their components manufactured at plants [2]. On-site MMC consist of traditional materials combined with innovative manufacturing processes. On-site MMC are realized and assembled directly onsite. 
Production of more or less completed components of building structures at plants has a high potential for increasing construction efficiency at the building components production stage as well as in the process of their integration in the site. MMC represent technologies that provide effective procedures for construction preparation and execution, resulting in a larger volume of production with higher quality and reduced time of their procurement [1],[3]. The advantages of MMC are shorter construction time, fewer errors in construction, higher quality building components and reduced demands on energy consumption or reduced construction waste generation. Their ambition, according to Burwood and Jess [4], is to enhance construction efficiency through reducing construction time, improve quality, sustainability and reduce the impact of a building and of the building process on the environment [5]. Lane [6], in its analysis of the obstacles to greater use of modern methods of construction, presents MMC as products and processes designed to improve business efficiency, quality, customer satisfaction, impact on the environment, sustainability and predictability of the deadline set. MMC is engaged in looking at the possibility of improving the performance and effectiveness in building a construction as a whole.

A range of materials is used for MMC, the most common being wood, steel and concrete but also a variety of modern materials based on plastics, composites, and other. The choice of basic building materials is a important part of each project and is usually based on professional judgment, taking into consideration the importance of such criteria as economic, environmental, functional, aesthetic and health-related [7]. Responses involving efficient, economic and sustainable solutions are Modern Methods of Construction based on wood. As for Modern Methods of Construction implementation aim on Slovak construction system. This system is designed for multi-storey buildings, apartment buildings, office buildings and houses [8]. According to Štefko [9], they can be built as prefabricated panel constructions, framed constructions, timbered constructions, skeleton or half-timbered constructions. One of the advantages of wooden houses is the range of structures and composition of walls, which can be designed at a low cost, with low energy and passive models. In addition, they are perceived as structures for 'healthy' housing, their main advantages being short construction time, lower environmental impact of construction and materials used, and lower realization and operation costs [1]. Manufacturing and construction of wooden buildings, from the point of view of production technologies and the materials used, has definitely a lower environmental impact compared to other, traditionally preferred technologies (in Slovakia, it is ceramic or silicate brickwork and monolithic reinforced concrete).

The currently according to Kozlovská et. al. [10], the quality of construction is characterized by the fact if the building is sustainable with emphasis on responsibility for society and environment. The sustainable building must be in compliance which ones are key characteristics of the building, expressing the quality of planning process, as optimization of environmental, economic and social parameters of the quality. All arguments of sustainability are beneficial for the demand for construction quality. According to a survey conducted by the agency STEM / MARK in year 2013 [10], quality is the decisive factor when purchasing building materials for $82 \%$ of Slovaks, while $91 \%$ are willing to pay extra for it. That means the suggestion, investors in the procurement of housing as a major factor prefer quality materials and therefore the operational quality of the building. Article evaluates quality performance of buildings through their users, because they know objectively as possible to assess the quality performance of his wooden buildings. 


\section{Materials and methods}

The subject of our research work are assembled wooden buildings could be regarded as one of the key methods of modern methods of construction used in our conditions, namely in the Central European region. The segment of the construction of wood-based houses is the most widespread segment in Slovakia. We examined in detail in particular the three most represented construction systems wooden houses, representative of on-site technologies (wooden constructions made on site) columnar and log construction and representative systems off-site technologies (prefabricated wooden houses) panel construction system of allwall sandwich panels. Examined structural systems will be investigated through the evaluation of the already constructed buildings. Evaluation is based on the experiences of these buildings users themselves, aimed on the occurrence and frequency of errors occurring just after moving-in and after a long time of use of buildings (1 to 10 years). According to our previous unpublished research users themselves have a real knowledge of multiannual use of wooden buildings and are able to assess the incidence of errors on their own experience. It is one of the possible impulses to influence potential customers through customer experience, which is already the "product" is used. For these reasons, we have chosen the users experience as the subject of research. In the next part of this article we focus on the characteristics of selected structural system and monitoring and analysis of errors buildings based products. The present research is a partial outcomes of the socio-economic survey (carried out during the years 2015-2017 within the Slovak Republic) oriented to detect the degree of efficiency and sustainability of modern methods of construction based wood. The survey was also monitoring constructional-technical characteristics of the buildings. Through the Pearson correlation coefficient we examined the degree of statistical dependence of selected parameters which influence the frequency of errors and quality construction.

\subsection{Selected construction systems buildings based on wood}

\subsubsection{Log construction system}

Log buildings are the successor of the traditional folk architecture of Slovak rural areas, especially in mountainous parts of Slovakia. External walls of these buildings are made of machined stem tree - log (prisms, pillows, regulation) (Fig.1). Wall connections are linked by the carpentry joints that ensure the overall structural rigidity. Log wall ensure also the heatinsulating function. Modern log construction are among the most environmentally friendly because in the "production" - the growth of "building material" leaves no residues - on the contrary removes pollutants [9]. 

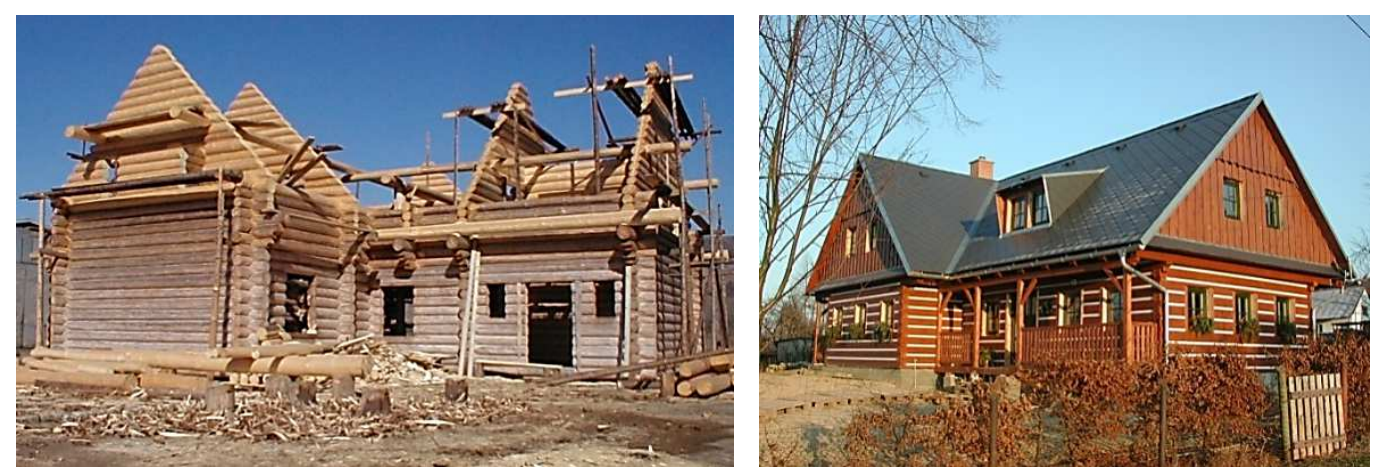

Figure 1: Log construction system [12], [13]

Characteristic features by Kolb [14] timbered construction systems are: high craftsmanship, a special selection of wood, high wood consumption, fixed layout footprint, volume and shape changes of the building. The log building require high craftsmanship, improved labor in assembling, there is a volume and shape changes of the building all of this features could be regarded as disadvantages, e.g. by Čuláková [16]. There are also substantial restrictions on, for example, number of floors and building placement, because according to architectural and urban planning rules, these buildings cannot be built anywhere.

\subsubsection{Wooden frame system}

Wooden frame system originates from USA and Canada, where it is still the most widely used building system. The basic element of such a construction is supporting frame perimeter and partition walls of various timber profiles (Fig.2). Ceiling structure is composed of different profiles of timber and wood based materials. The stability is provided by the cladding of large agglomerated materials such as OSB board or gypsum board. Thermal requirements are secured by inserting thermal insulation (Fig.3). Standard construction of the walls is similar to panel construction system, but the individual elements and layers of walls are completed directly on site.

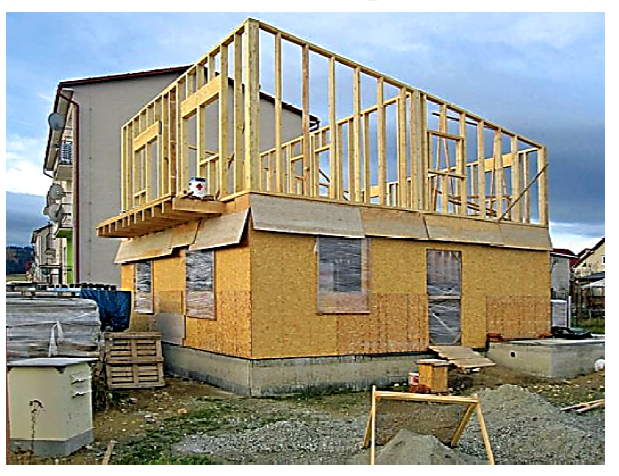

Figure 2: Wooden frame system [17]

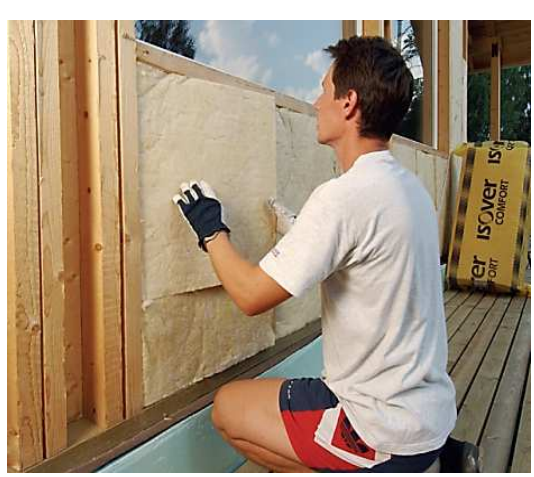

Figure 3: Inserting thermal insulation of walls [17]

Construction and assembly of wooden frame system is less demanding on a large mechanization. All layers of the structure and operation of installations are carried out on site, resulting in higher labor demands a higher proportion of the on-site works. This causes a greater probability of low quality work, including the impact of climatic conditions. 


\subsubsection{Panel construction system}

Panel construction system is a main off-site construction method based on wood. Structural elements - panels (wall, ceil, roof, gable, partition wall) are produced in different stages of completion in the production hall and subsequently transported to the construction site where they are assembled to the structure. Build-up process is characterized by speed and precision. The panel generally consists of a wooden frame of profiled timber, covered on both sides with large-scale plates, filled with thermal insulation material. Instalations are prearranged in the panels during the manufacturing.
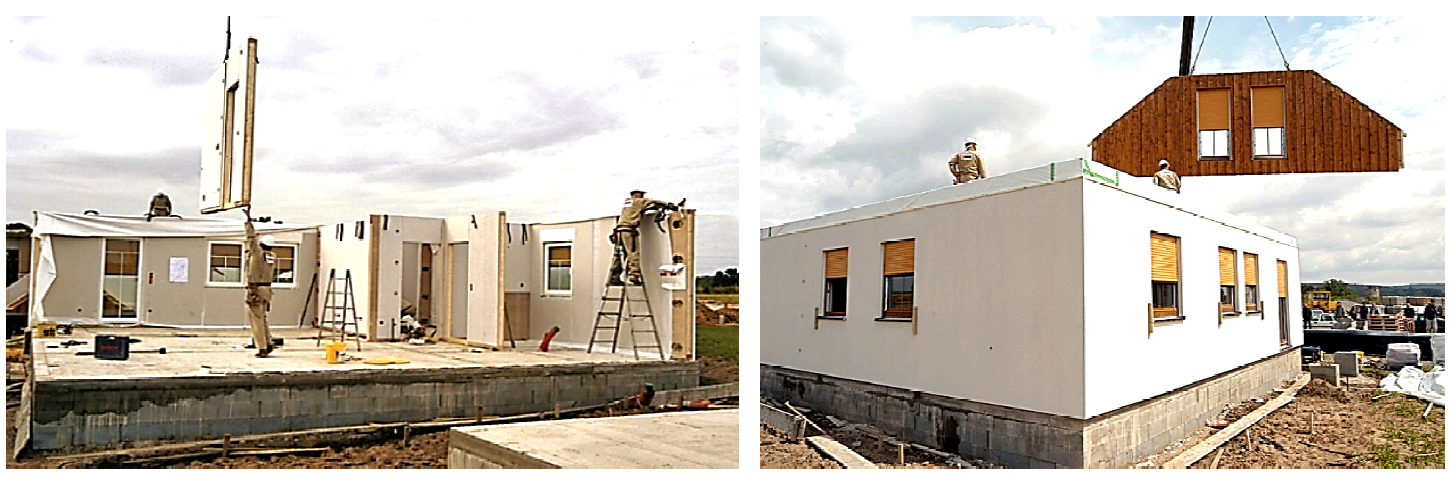

Figure 5: Construction of panel construction system [19]

Prefabricated construction panel system fully utilizes construction, manufacturing and assembly advantages of their production to the efficiency of the entire construction process. The key moment to increase the efficiency and degree of prefabrication is panel's finalization. Panel system has enormous potential for increasing efficiency in the design, production and construction phase. Manufacturing can be automated, thus increasing the quality of production. Load bearing system of prefabricated wooden houses could be completed within a few days (Fig.5). Other finishing and plumbing work follows the assembly of the individual elements.

\section{Results and discussion}

The research presents partial results of the socio-economic survey. Specifically, the section devoted to present quality assessment of buildings. A total of 103 assembled wooden buildings were evaluated. Most numerous group were the construction of prefabricated construction systems of all-wall sandwich panels in the number of 45 houses were the second largest group of buildings on the basis of a columnar construction of wooden houses in the 35 $\log$ houses and timbered wooden houses represents the number of 23 buildings. A period of use was also observed in the survey. Most numerous group of the wooden buildings was with 1-5 years duration of use (Table 1). Period of use of individual wooden buildings demonstrates a sufficiently long period of use for the actual assessment of the buildings by their users in our opinion. 
Table 1: Time of use of the analyzed homes

\begin{tabular}{|l|c|c|c|}
\hline Time of use (years) & to 1 year & from 1 to 5 years & Over 5 years \\
\hline $\begin{array}{l}\text { Percentage } \\
\text { representation }\end{array}$ & $31 \%$ & $42 \%$ & $27 \%$ \\
\hline
\end{tabular}

This sub-section also presents the effectiveness in terms of quality through selected data sets results intended to assess occurrence of errors at the beginning and during the use of assessed buildings. Evaluation of degree occurrence errors after moving in and during use wooden buildings through customer rating is shown in Fig.6. Users have the ability to scale errors from 0 (no error) to 5 (high incidence of errors) in two phases. The first phase was the early use of the building (after moving-in) and the second phase of mapping the error with the passage of time during use of the building.

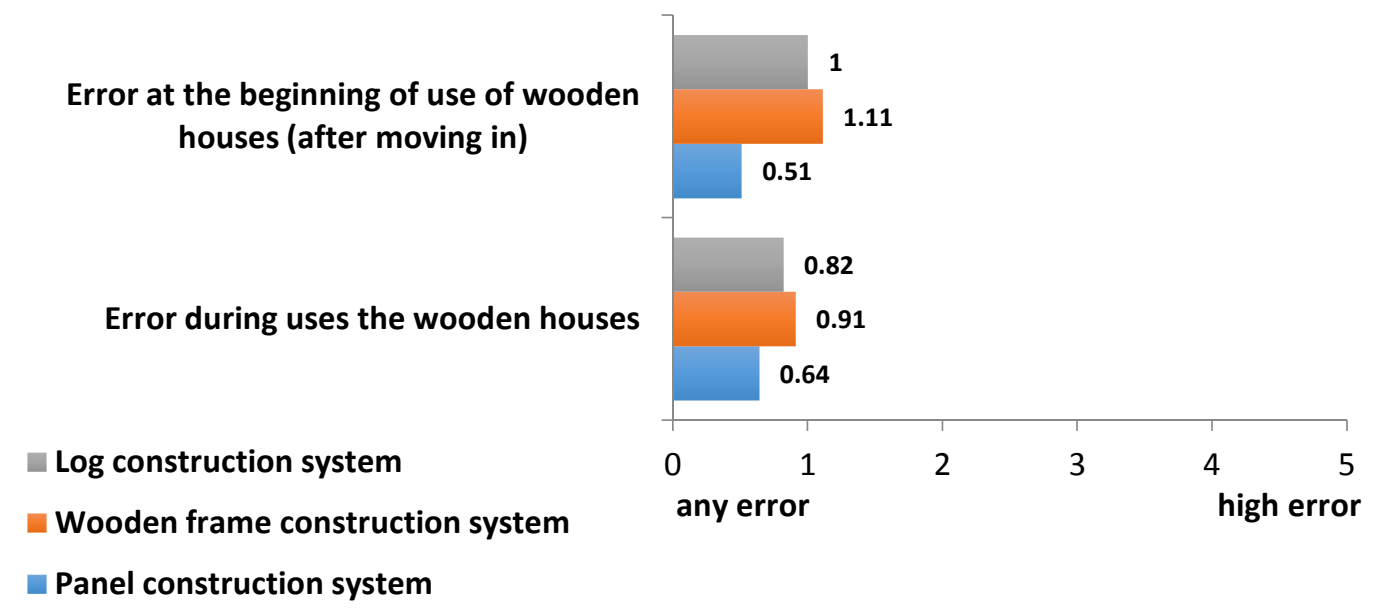

Figure 6: Degree of occurrence errors after moving in and during uses the wooden buildings

The most positive rating was reached by a panel construction system, subsequently by log construction system and timber frame buildings were evaluated as the worst system in opinion of their users. Similar findings have also been reported in the assessment of defects during use but with lower intensity evaluation of the occurence. In the respective evaluation stages enable users to designate specific defects that have been reported during use of buildings. The percentages of occurrences of the errors in the evaluated phases are shown in Fig. 7 and Fig. 8 according to the respective rated structural wood building systems.

Figure 7 presents the percentage of the frequency of different types detected errors based on user ratings wood building after moving in.

According to the findings (Fig.7) at the beginning of use is after moving in the users have recorded the least number of errors in the panel construction system, followed by the $\log$ construction and a timber frame construction system. The most commonly found errors related to the construction details pertain to the formation of surface defects. Other errors were not related to specific construction systems but they occurred also in the connection with the technical infrastructure involved and could be considered as a minor failures in regard to the structural, load bearing system. 


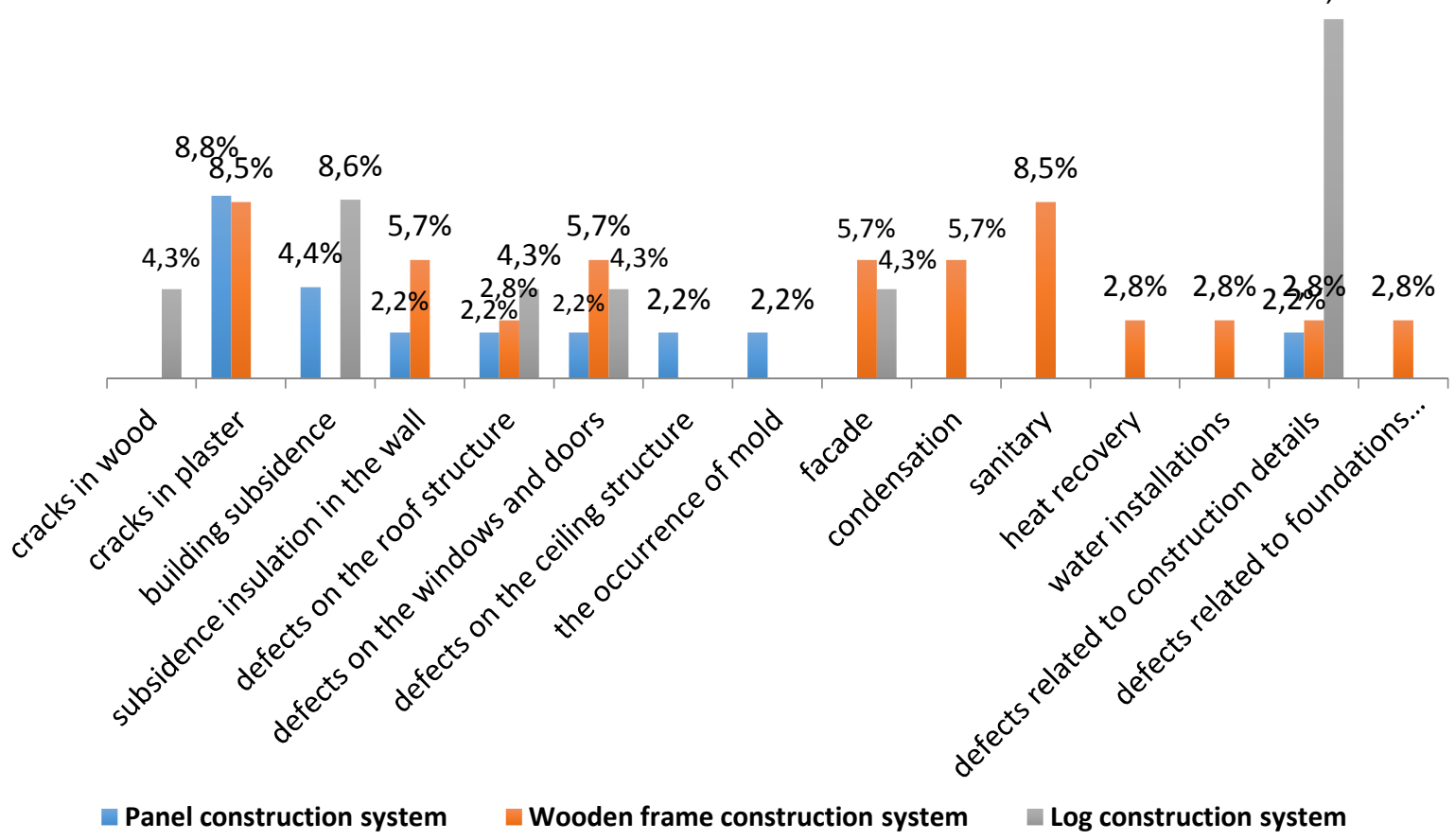

Figure 7: Frequency of different types of errors at the beginning of use of the building (after moving in).

Figure 8 presents the percentage of detected errors based on user ratings particular wooden buildings in the phase of during uses.

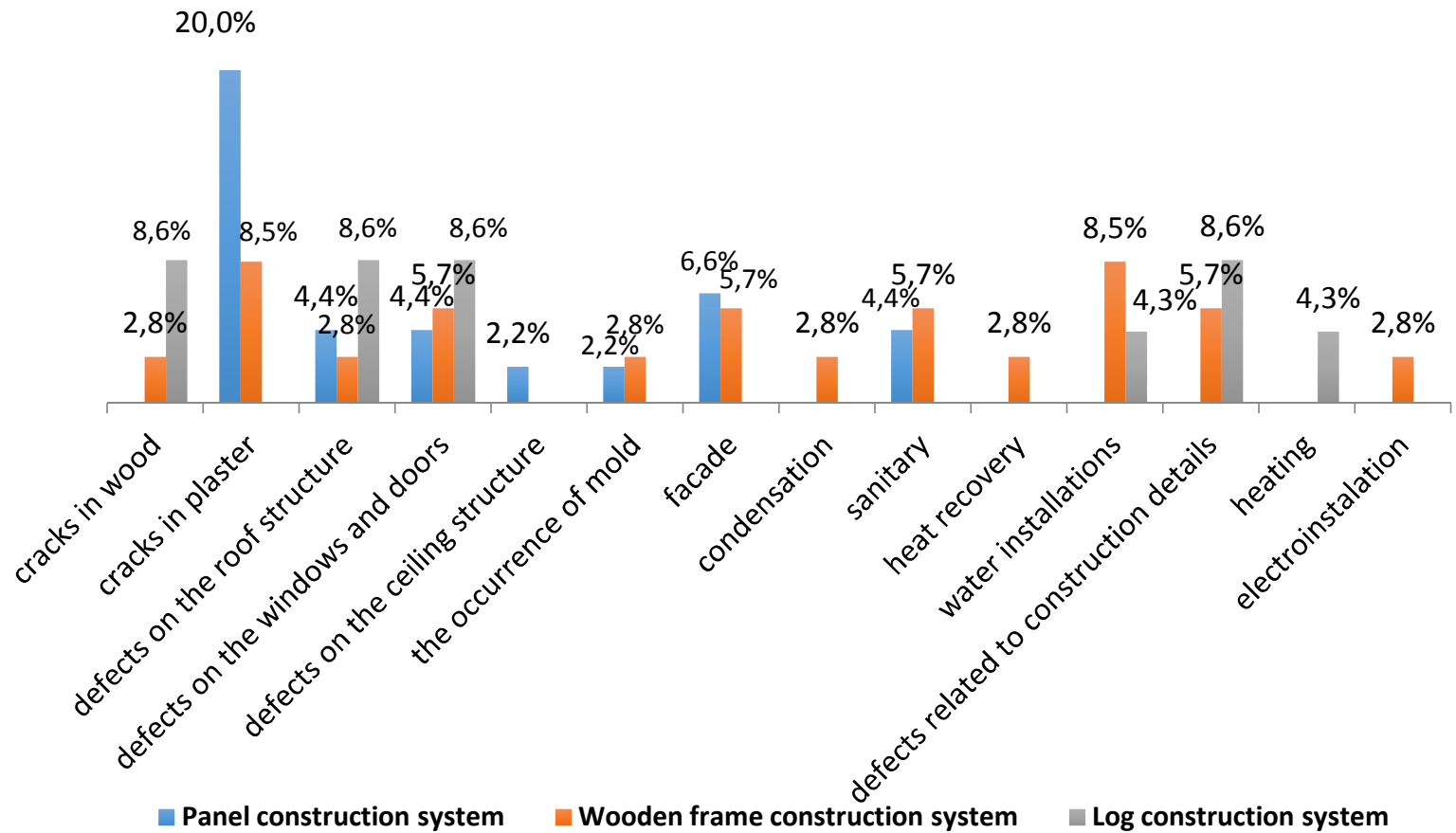

Figure 8: Frequency of different types of defects during use of the building.

Using correlation analysis on the significance ( $\mathrm{p} \square 0,05)$, we found a statistically significant relationship between the construction time and a error occurs during use of the building $(\mathrm{P}=$ 
0.2043). The longer the construction took, the greater the number of errors during use. This is confirmed by the finding that the average construction time of prefabricated wooden buildings was the shortest of the compared systems and the construction of prefabricated timber construction showed at the lowest observed defect rate and its manufacturing was evaluated as of the highest quality comparing to the other structural systems. Errors discovered during use of the building were mostly related to construction details associated with structural defects. We also found a statistically significant positive correlation between the occurrence of defects after moving-in and defects that occured after a long time of use $(\mathrm{P}=0.5010)$. This means that if increase the frequency of errors after moving in there was a statistically significant increase in the incidence frequency of errors during the use of buildings.

The main advantage of the panel construction system-is the possibility of preparing the maximum construction in manufacturing, quick installation and completion of construction at the building site. The bulk of the production of prefabricated wooden buildings is tempered in the production hall, where there is no wetting of materials, effects of weather conditions while the panel can be put in a more accessible position so that assembly can be implemented thoroughly. Directly to the construction workers will not affect the position of structures according to the ideal position opposite the building construction at the site (on-site) workers must implement various scaffolding and support construction for implementing the necessary processes. In terms of quality assurance in the columnar and log system is considerably more processes at the site exposed to the potential risk of poor quality, whether as a result of noncompliance with operating procedures, staff incompetence or due to adverse weather conditions mentioned on the site. Semi or fully automatic lines can even eliminate the work of the people, that the greatest risk factor. Similar considerations can be distributed also in the field of occupational safety and waste production.

\section{Conclusion}

Analyses of qualitative parameters of buildings have been identified reserves and weaknesses of the various construction systems based on wood that can provide particular manufacturers an ideal area for improving the quality of processes and products, thus building. Evaluation of qualitative parameters revealed differences between the compared construction systems that flow already in its construction and technical potential of the technology. According to the findings at the beginning of use is after moving in the user has recorded the least errors in panel construction system, followed by the system timbered construction and a column construction system. The most commonly found errors relate to construction details pertain to the formation of errors on the surfaces of structures. Other errors were not related to specific construction systems but also concerned total technical equipment of what we consider minor disorders related to structural systems. Errors found during use of the building were mostly related to construction details that have been associated with errors in structures. We also found a statistically significant positive correlation between the occurrence of defects after moving and error occurs after a long time of use $(\mathrm{P}=0.5010)$. This means that if it was found to increase the frequency of errors after moving in there was a statistically significant increase in the incidence frequency of errors during the use of buildings. Analyses show that the panel structures are the best rated in terms of quality assessment among other technology based on wood. The research indicates some errors which 
can be eliminated through processes and products innovation in the next production of modern method of construction based on wood.

\section{Acknowledgements}

The article presents a partial research result of the VEGA project - 1/0677/14 Research on Construction Efficiency Improvement through MMC Technologies".

\section{References}

[1] Smith R. E., Timberlake J. (2011). Prefab Architecture: a Guide to Modular Design and Construction, Canada.

[2] Lovell H., Smith S. J. (2010). Agencement in Housing Markets, The Case of the UK Construction Industry. Geoforum 41, 457-468. DOI 10.1016/j.geoforum.2009.11.015.

[3] Arif M., Egbu C. (2010). Making a Case for Offsite Construction in China. ECAM 17, 536-548. DOI 10.1108/09699981011090170.

[4] Burwood S., Jess P. (2005). Modern Methods of Construction Evolution or Revolution, A BURA Steering and Development Forum Report.

[5] Blismas N., Wakefield R. (2009). Concrete Prefabricated Housing via Advances in Systems Technologies, Development of a Technology Roadmap. ECAM 17, 99-110. DOI 10.1108/09699981011011357.

[6] Lane A. (2006). Barriers and Solutions to the Use of Modern Methods of Construction.

[7] Lesniak A., Zima K. (2015). Comparison of Traditional and Ecological Wall System Using the AHP Method. In: International Multidisciplinary Scientific GeoConference Surveying Geology and Mining Ecology Managamentt, SGEM 2015:3(5), 157-164.

[8] Thanoon W. A. M. et al. (2003). The Essential Characteristics of Industrialised Building System, International Conference on Industrialised Building Systems, Malaysia.

[9] Štefko, J., Reinprecht, L. (2004). Dřevěné stavby - konstrukce, ochrana a údržba, Jaga group.

[10] Kozlovská, M., Struková, Z., Tažiková, A. (2014). Integrated assessment of buildings quality in the context of sustainable development principles, Quality innovation prosperity 18/2, 1-16.

[11] Čellár, J. (2016), Stavby v rovnováhe, Retrieved March 20, 2016, from http://www.fordom.sk/files/File/clanky/Sab032012.pdf

[12] Ceder, (2014) Zrubové stavby, Retrieved November 10, 2014, http://www.ceder.sk/cennik.html

[13] Reinprecht, L. (2005). Zrubový konštrukčný systém, Retrieved November 10, 2015, http://mojdom.zoznam.sk/cl/10027/95558/Zrubovy-konstrukcny-system

[14] Kolb, J. (2008). Dřevostavby, Grada Publishing, Praha.

[15] Lepšie bývanie.sk, (2006). Ako sa býva v zrube, Retrieved September 20, 2016, http://lepsiebyvanie.centrum.sk/staviame/219935/ako-sa-byva-v-zrube?print

[16] Čuláková, M. (2013). Katalóg stavebných konštrukcii drevostavieb, Retrieved September 20, 2014, https://sites.google.com/site/hodnoteniebudov/home/katalog-stavebnych-konstrukciidrevostavieb 
[17] Dubjel, K., Bobeková, E. (2012). Realizácia rodinného domu drevenou stĺpikovou sústavou, Retrieved October 28, 2016, http://www.asb.sk/stavebnictvo/drevostavby/realizacia-rodinnehodomu-drevenou-stlpikovou-sustavou

[18] Marshal-cz, Výrobné haly pre drevostavby, Retrieved October 28, 2016, http://www.marshalcz.cz/13958/montazni-stoly-na-vyrobu-sendvicovych-panelu/

[19] Haas Fertigbau (2016). Montované domy, Retrieved November 18, 2016, http://www.haasfertigbau.sk/rodinne-domy/

[20] Mesároš P., Mandičák T., Selín J. (2015). Modern Methods for Cost Management in Construction Enterprises, Journal of Civil Engineering, Selected Scientific Papers 10/2015, 111-120.

[21] RNAO Report by the National Audit Office (2005). Using Modern Methods of Construction to Build Homes More Quickly and Efficiently.

[22] Slovak federation for processors of wood. (2015).

[23] Smola J. (2011). The Construction and Use of Low-Energy and Passive Houses, Grada.

[24] Vaverka J., Havírová Z., Jindrák M. et al. (2008). Wood Construction for Living, Grada Publishing, Prague. 